
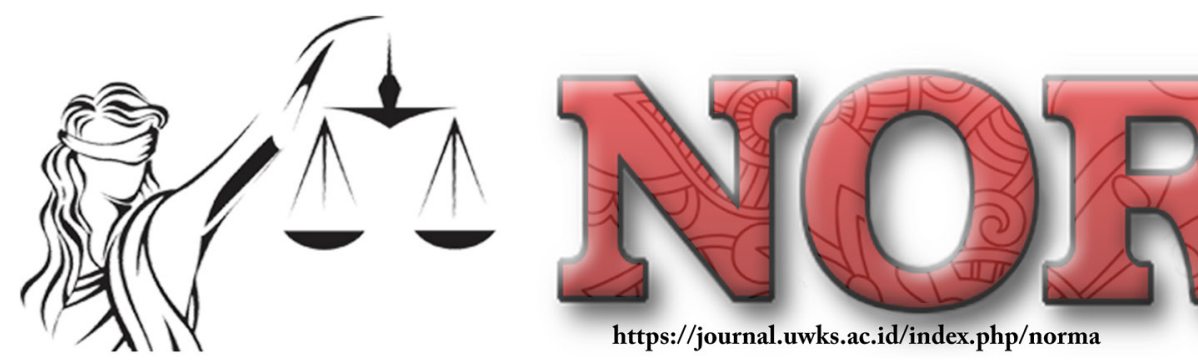

\title{
Case Review of Surabaya District Court Decision No. 672/ Pdt.G/2016/PN.Sby about Unlawful Sale and Purchase Agreement of Land and Building
}

\author{
Ramzi Maulana Arghie \\ Legal Observer \\ e-Mail: ramzimaulanaarghie23@gmail.com
}

\begin{abstract}
:
The research, entitled Case Study of Surabaya District Court Decision No. 672/Pdt.G/2016/PN.Sby about Unlawful Sale and Purchase Agreement of Land and Building aims to find out whether or not Dirk Tatipata is said to have defaulted on the Sale and Purchase Agreement (PPJB) of land, which he did with Ronald Sanjaya, how the legal protection for Dirk Tatipata as the party who was harmed by the decision of the Surabaya District Court, This is normative legal research, Based on the results of the study, it can be concluded that legally, it is clear that Dirk Tatipata does not have high bargaining power and is a seller of land and buildings on Jl. Sleep No. 103 that has been done in front and signed by Notary Anita Lucia Kendarto, S.H., M.Kn. with several letters/deeds. Thus, legal resistance is still being carried out by carrying out a lawsuit in the land and building dispute case at the Surabaya District Court, and ending his defeat coupled with a penalty of trial fees and payment for his unlawful actions harmed Ronald Sanjaya as the legal owner of the land and buildings.
\end{abstract}

Keywords: Agreement; Against the Law; Unlawful Sale.

Article's History:

Received:

June 17, 2021;

Peer-Reviewed:

June 21, 2021;

Accepted:

July 15, 2021;

Published:

July 30, 2021.

DOI:

10.30742/nlj.v18i2.1589

\section{INTRODUCTION}

The land is an essential thing in human life. Therefore, most Indonesian people live from an economy that depends on land to live or work. In addition, the rapid growth of Indonesia's population, causing the need for land or land to increase and ultimately causing land prices to be higher, especially in urban areas. Soil is part of the earth, which is called the earth's surface. Land meant here does not regulate land in all aspects but only handles one aspect, namely land in a juridical sense called land rights.

As regulated in Law Number 5 of 1960 concerning Basic Agrarian Regulations or better known as the Basic Agrarian Law, referred to as (UUPA). In Indonesia, there have been two legal systems regarding land. Namely, Land Law based on Customary Law and Land Law based on Western Law contained in the Burgelijk Wetboek from now on referred to as BW. ${ }^{1}$

${ }^{1}$ Fani Martiawan Kumara Putra, "Pembatalan Sertipikat Hak Atas Tanah Karena Cacat Administratif Serta Implikasinya Apabila Hak Atas Tanah Sedang Dijaminkan," Perspektif 20, no. 2 (2015): 101-17. 
To own land can be through buying and selling, which is usually done through a sale and purchase agreement. The sale and purchase agreement has been regulated in the Civil Code where Article 1458 (Civil Code) reads: "The sale and purchase are considered to have taken place between the two parties when they have reached an agreement on the goods and the price, even though the goods have not been delivered or the price has not been paid."

According to Article 1457 of the Civil Code, it is stated that the sale and purchase of land is an agreement with which the sale binds him (his heart promises to hand over the land in question to the buyer who attaches himself to pay the seller the agreed price). However, sometimes it can run not according to the deal that all parties expect in an agreement.

In mid-2015, the Plaintiffs as to the heirs of Endang Hartini, the wife of Dirk Tatipata (Plaintiff I) and the biological mother of the three daughters between Endang Hartini and Dirk Tatipata, were named Andriana Oknova (Plaintiff I's First Daughter) (called Plaintiff II), Wisye Christina Tatipata (Plaintiff I's Third Daughter) (referred to as Plaintiff III), Meutia Expertise Tatipata, (Plaintiff I's Second Daughter) (referred to as Plaintiff IV). The three daughters of Plaintiff I intend to seek a business capital loan, starting with Plaintiff II meeting Brother Radit as an intermediary and introducing Defendant I to offer a business capital loan.

Before getting to know Defendant I, Plaintiff II first knew Mr. Radit (a confidant of Defendant I). Mr. Radit conveyed the agreement for a business capital loan with a total disbursement of Rp. 6,375,000,000,- (six billion three hundred seventy five million rupiah). Then it was agreed on the calculation of interest and loan repayments in full with the Pre-Contract between the Plaintiffs and Defendant I with the following details: Total working capital of Rp. 7,648,000,000,- (seven billion six hundred and forty-eight million rupiah) minus 15\%, then the Plaintiffs received Rp. 6.500,000,000, - (six billion five hundred million rupiah). The second month the Plaintiffs had to pay the interestonly with a calculation of Rp. 382.400.000,- (three hundred eighty-two million four hundred thousand rupiah). Furthermore, the Plaintiffs at the time of returning the business capital must pay Defendant I in full in the amount of Rp. 7,648,000,000,- (seven billion six hundred forty eight million rupiah). It was agreed on the Pre-Contract that a total return of Rp. 7,687,500,000,- (seven billion six hundred eighty-seven million five hundred thousand rupiah) plus a fee that the Plaintiffs have not paid in the amount of Rp. 440.000.000,- (four hundred and forty million rupiahs), so that the total is Rp. 8,127.500.000,- (eight billion one hundred twenty-seven million five hundred thousand rupiahs).

The business capital loan was made on December 16, 2015, with a Sale and Purchase Association (IJB) concept at Notary Anita Lucia Kendarto, S.H., M.Kn. (Defendant II), having its office at Ruko Office Par B-1 Number 5, Jl. Darmo Boulevard 
Hill, Surabaya. When reading the nominal value signed by Plaintiff I and Defendant I, I was Rp. 2.800,000,000,- (two billion eight hundred million rupiahs).

On April 1, 2016, Plaintiff II visited Notary Anita Lucia Kendarto, S.H., M.Kn. (Defendant II), to request a copy of the Sale and Purchase Agreement (IJB), Plaintiff II felt that there were other irregularities in the Sale and Purchase Agreement (IJB), including First, the Sale and Purchase Agreement (IJB) Number 75, which Defendant II readout with a nominal value of Rp. . 2,800,000,000, - (two billion eight hundred million rupiah) but in the Sale and Purchase Association (IJB) it is written Rp. 4.500,000,000, (four billion five hundred million rupiah). Second, a loan that uses the concept of a Sale and Purchase Agreement (IJB) with several payments, while in the editorial, the Sale and Purchase Agreement (IJB) is stated as a Down Payment and settlement of the sale and purchase of a house when in fact there is no sale and purchase agreement between the parties. Plaintiff and Defendant I. Third, in the Sale and Purchase Agreement (IJB), there is an absolute power of attorney clause as stated in Article 4 of the Sale and Purchase Association (IJB) Number 75, which reads:

"The First Party hereby authorizes the Second Party, for and on behalf of the First Party with a Deed of Power of Attorney dated today, the next number is drawn up before me, the Notary. The Deed of Power in question is an inseparable part of this agreement. Therefore it cannot be revoked or becomes null and void, and is granted by releasing all legal regulations that determine the causes for the termination of a power of attorney".

Concerning the explanation above, this study will review the case of the sale and purchase of land and buildings on Jl. Sleep No. 103 City of Surabaya between Plaintiff Dirk Tatipata's family and Defendant Ronald Sanjaya.

\section{RESEARCH METHOD}

This is normative legal research with a statute approach.

\section{DISCUSSION}

\section{Legal Facts}

The Surabaya District Court handled the legal case with Decision Number: 672/ Pdt.G/2016/PN. Sby is a case between the Plaintiffs and the Defendants consisting of:

1. Plaintiff I: Dirk Tatipata, 80 years old (Land and building seller);

2. Plaintiff II: Andriana Oknova, 55 years old (Plaintiff I's first daughter);

3. Plaintiff III: Wisye Christina Tatipata, 52 years old (Plaintiff I's third daughter);

4. Plaintiff IV: Meutia Expertise Tatipata, 54 years old (2nd daughter of Plaintiff I). The case handled by the Surabaya District Court was a case between Dirk Tatipata (Plaintiff I), who originally intended to develop a family company business by guaranteeing a Certificate of Ownership (SHM) Number: 4218 NIB. 12.01.06.05.05655, 
covering an area of 490 M2, located on Jl. Sleep No. 103, Petemon Village, Sawahan District, Surabaya on behalf of the rights holder Dirk Tatipata.

In the mediation process at the Surabaya District Court, the Defendants had good intentions. Still, the Plaintiffs did not show their goodwill to resolve this case through mediation following the applicable laws and regulations.

The Mediator Judge st a ted that the mediation process failed because it was seen from only Plaintiff II, who was present at the initial mediation meeting, but never attended the next mediation meeting even though he had been appropriately summoned 2 (two) times in a row without valid reasons from 3 (three) times of summons for mediation. The Panel of Judges who examined, tried, and decided this case not to accept the Plaintiff's claim who did not have good intentions, thus could be used as one of the reasons in the Judge's decision.

\section{Legal Considerations}

At the trial on Thur sday, December 1, 2016, the mediator Judge became the examining Judge, asking the Panel of Judges who examined, tried, and decided the case not to accept the Plaintiffs' claims due to formal defects. In the main issue, the following items were found:

1. Defendant expressly rejects all the arguments of the Plaintiffs;

2. Certificate of Ownership (SHM) Number 558 (Surat Ukur Number 1372 of 1988) on behalf of Plaintiff I to Certificate of Ownership (SHM) Number 4218 (Surat Ukur Number 00833 of 2015) on behalf of Defendant I on March 18, 2016, is valid and legal;

3. The Plaintiffs' arguments stating the debts are fabricated and untrue;

4. On December 16, 2015, the Sale and Purchase Binding Agreement (PPJB) Number 75, Power to Sell Number 76, and Employment Agreement Number 77 were made. Defendant paid in full the entire sale and purchase of the house.

Legally, it is clear that Dirk Tatipata does not have high bargaining power and is a seller of land and buildings on Jl. Sleep No. 103 that has been done in front and signed by Notary Anita Lucia Kendarto, S.H., M.Kn. with several letters/deeds, namely:

1. Sale and Purchase Binding Agreement (PPJB) Number 75 dated December 16, 2015, made and signed before Notary Anita Lucia Kendarto, S.H., M.Kn;

2. Authorization to Sell Number 76, dated December 16, 2015, made and signed before Notary Anita Lucia Kendarto, S.H., M.Kn;

3. Employment Agreement Number 77, dated December 16, 2015, was made and signed before Notary Anita Lucia Kendarto, S.H., M.Kn;

4. Deed of Sale and Purchase (AJB) Number 99/2016 dated March 2, 2016, drawn up and signed before Notary Anita Lucia Kendarto, S.H., M.Kn.

Thus, legal resistance is still being carried out by carrying out a lawsuit in the land and building dispute case at the Surabaya District Court, and ending his defeat coupled 
with a penalty of trial fees and payment for his unlawful actions harmed Ronald Sanjaya as the legal owner of the land and buildings.

\section{CLOSING}

\section{Conclusion}

The binding sale and purchase agreement (PPJB) of land between Mr. Dirk Tatipata and Mr. Ronald Sanjaya on December 16, 2015 Number 75 is valid and binding with a Power of Attorney to Sell Number 76 dated December 16, 2015, Employment Agreement Number 77 dated December 16, 2015, which were all drawn up and signed before Notary Anita Lucia Kendarto, SH, M.Kn. Also equipped with the Sale and Purchase Deed (AJB) Number 99/2016 dated March 2, 2016, made and signed before Notary Anita Lucia Kendarto, S.H., M.Kn. Dirk Tatipata Brother is said to have committed an unlawful act on the Land Purchase Agreement (PPJB), which he did with Ronald Sanjaya since the agreement was made on December 16, 2015, until the Surabaya District Court decision on June 18, 2017, still has not carried out its obligations to vacate the land. And the building. In legal protection for Mr. Dirk Tatipata as the losing party in the lawsuit, Ronald Sanjaya proved a Letter/Deed of Sale and Purchase dated March 2, 2016.

\section{Recommendation}

For the community in carrying out legal actions, the author recommends that they be careful in carrying out lawful activities such as making any form of agreement to study article by article in the contract. It is not easy to file a lawsuit, as the author raised if the initial goal is to obtain business capital by guaranteeing a Certificate of Ownership (SHM), but what is carried out in the legal process is a sale and purchase. A lawsuit is filed, then as the initial owner and has made a sale before a Notary, of course, he does not have rights to the land and buildings.

\section{REFERENCES}

Putra, Fani Martiawan Kumara. "Pembatalan Sertipikat Hak Atas Tanah Karena Cacat Administratif Serta Implikasinya Apabila Hak Atas Tanah Sedang Dijaminkan." Perspektif 20, no. 2 (2015): 101-17. 